\title{
Evidence for a Role of Transporter-Mediated Currents in the Depletion of Brain Serotonin Induced by Serotonin Transporter Substrates
}

\author{
Michael H Baumann', Simon Bulling', Tova S Benaderet', Kusumika Saha ${ }^{2}$, Mario A Ayestas', \\ John S Partilla', Syed F Ali ${ }^{3}$, Thomas Stockner², Richard B Rothman', Walter Sandtner ${ }^{2}$ and \\ Harald H Sitte*,2 \\ 'Medicinal Chemistry Section, Intramural Research Program (IRP), NIDA, NIH, Baltimore, MD, USA; ${ }^{2}$ Center for Physiology and \\ Pharmacology, Institute of Pharmacology, Medical University Vienna, Vienna, Austria; ${ }^{3}$ Neurochemistry Laboratory, Division of Neurotoxicology, \\ National Center for Toxicological Research (NCTR), FDA, Jefferson, AR, USA
}

\begin{abstract}
Serotonin (5-HT) transporter (SERT) substrates like fenfluramine and 3,4-methylenedioxymethamphetamine cause long-term depletion of brain 5-HT, while certain other substrates do not. The 5-HT deficits produced by SERT substrates are dependent upon transporter proteins, but the exact mechanisms responsible are unclear. Here, we compared the pharmacology of several SERT substrates: fenfluramine, d-fenfluramine, I-(m-chlorophenyl)piperazine (mCPP) and I-( $m$-trifluoromethylphenyl)piperainze (TFMPP), to establish relationships between acute drug mechanisms and the propensity for long-term 5-HT depletions. In vivo microdialysis was carried out in rat nucleus accumbens to examine acute 5-HT release and long-term depletion in the same subjects. In vitro assays were performed to measure efflux of $\left[{ }^{3} \mathrm{H}\right] 5-\mathrm{HT}$ in rat brain synaptosomes and transporter-mediated ionic currents in SERT-expressing Xenopus oocytes. When administered repeatedly to rats $(6 \mathrm{mg} / \mathrm{kg}$, i.p., four doses), all drugs produce large sustained elevations in extracellular 5-HT (>5-fold) with minimal effects on dopamine. Importantly, 2 weeks after dosing, only rats exposed to fenfluramine and $d$-fenfluramine display depletion of brain $5-\mathrm{HT}$. All test drugs evoke fluoxetine-sensitive efflux of $\left[{ }^{3} \mathrm{H}\right] 5-\mathrm{HT}$ from synaptosomes, but $d$-fenfluramine and its bioactive metabolite $d$-norfenfluramine induce significantly greater SERT-mediated currents than phenylpiperazines. Our data confirm that drug-induced 5-HT release probably does not mediate 5-HT depletion. However, the magnitude of transporter-mediated inward current may be a critical factor in the cascade of events leading to 5-HT deficits. This hypothesis warrants further study, especially given the growing popularity of designer drugs that target SERT. Neuropsychopharmacology (2014) 39, I355-1365; doi:I0.I038/npp.20I3.33I; published online 5 February 20I4
\end{abstract}

Keywords: serotonin (5-HT) release; 5-HT depletion; 5-HT transporter (SERT); SERT substrate; SERT-mediated current

\section{INTRODUCTION}

The amphetamine analogs fenfluramine and $d$-fenfluramine (here referred to collectively as fenfluramines) were widely prescribed appetite suppressants until they were withdrawn from clinical use because of the occurrence of valvular heart disease (Connolly et al, 1997; Rothman and Baumann, 2009). In addition to adverse cardiovascular effects, fenfluramines are known to cause long-term ( $>2$ weeks) deficits in brain serotonin (5-HT) neurons in animal models (McCann et al, 1997; Rothman and Baumann, 2002). Characteristics of this apparent degeneration include depletion of brain tissue

\footnotetext{
* Correspondence: Professor HH Sitte, Center for Physiology and Pharmacology, Institute of Pharmacology, Medical University Vienna, Waehringerstrasse 13 A, Vienna 1090, Austria, Tel: +43 | 4016031323 , Fax: +43 | 40160 931300, E-mail: harald.sitte@meduniwien.ac.at Received 31 May 2013; revised 25 October 2013; accepted 16 November 2013; accepted article preview online 28 November 2013
}

5-HT, impaired transmitter biosynthesis, and decreased 5-HT transporter (SERT) binding and function (Appel et al, 1990; Kleven and Seiden, 1989; Sanders-Bush et al, 1975; Zaczek et al, 1990). The prolonged effects of fenfluramines are mimicked by other ring-substituted amphetamines like p-chloroamphetamine (PCA) and 3,4-methylenedioxymethamphetamine (MDMA), and have been interpreted as evidence for 5-HT neurotoxicity (McCann et al, 1997; Steinkellner et al, 2011; Xie et al, 2006). On the other hand, some investigators have argued that effects of fenfluramines on brain 5-HT systems represent adaptive changes, rather than true neurotoxicity (Gobbi et al, 1996; O'Callaghan and Miller, 1994).

The precise mechanisms underlying the ability of fenfluramines to induce 5-HT deficits are not completely understood. Early in vitro studies reported that acute effects of fenfluramine involve inhibition of 5-HT uptake and stimulation of 5-HT release (Fuxe et al, 1975; Garattini et al, 1975). In vivo microdialysis studies in rats confirm that 
acute administration of fenfluramines elevates extracellular 5-HT in intact brain (Schwartz et al, 1989; Series et al, 1994). It is now well established that fenfluramines, like other ring-substituted amphetamines, are substrates for SERTs that evoke non-exocytotic release of 5-HT via reversal of normal transporter flux (Berger et al, 1992; Schuldiner et al, 1993; Sitte et al, 2000). Importantly, SERT blockers such as fluoxetine prevent both the acute 5-HT release and long-term 5-HT depletion produced by fenfluramine administration (Clineschmidt et al, 1978; Sabol et al, 1992; Steranka and Sanders-Bush, 1979), suggesting that 5 -HT release might somehow be involved in mediating persistent deficits (Berger et al, 1992; Halladay et al, 2001; Sabol et al, 1992). There is evidence, for example, that drug-induced release of 5-HT can lead to the formation of reactive 5-HT metabolites that can cause cellular damage (Commins et al, 1987; Seiden and Sabol, 1996; Wrona and Dryhurst, 2001).

In previous experiments (Baumann et al, 2001), we demonstrated that the SERT substrates, $d$-fenfluramine and 1-( $m$-chlorophenyl)piperazine (mCPP), elevate extracellular 5 -HT in rat brain by an analogous mechanism. Interestingly, when these drugs are administered repeatedly to rats, only $d$-fenfluramine causes long-term depletion of forebrain $5-\mathrm{HT}$. We concluded from these results that (1) 5-HT release per se may not be sufficient to produce drug-induced 5 -HT depletion and that (2) only certain SERT substrates are associated with long-term deficits. Consistent with our findings using $\mathrm{mCPP}$, a number of subsequent reports have identified SERT substrates devoid of neurotoxic properties (Gobbi et al, 2008; Rothman et al, 2005). However, a key limitation of all previous studies is that none have compared the effects of SERT substrates on acute 5-HT release and long-term transmitter depletion in the same subjects. Furthermore, few investigations have identified any fundamental difference between SERT substrates, which cause 5-HT depletion and those that do not.

In this study, we sought to address these issues by systematically comparing the acute and long-term effects of specific SERT substrates: fenfluramine, $d$-fenfluramine, mCPP and 1-( $m$-trifluoromethylphenyl)piperazine (TFMPP). We chose to examine these specific drugs because they have little effect on dopamine transmission (Baumann et al, 2001; Eriksson et al, 1999) and do not cause hyperthermia (Cryan et al, 2000; Malberg and Seiden, 1997), two factors that can simplify the interpretation of data from in vivo experiments. In vivo microdialysis was carried out in rat nucleus accumbens to determine the relationship between drug-induced 5-HT release and long-term 5-HT depletion in the same subjects. In vitro assays were performed to examine the ability of drugs to release preloaded $\left[{ }^{3} \mathrm{H}\right] 5-\mathrm{HT}$ from synaptosomes and to evoke transporter-mediated ionic currents in SERT-expressing Xenopus oocytes. Our data show that all of the test drugs are SERT substrates capable of releasing 5-HT in vitro and in vivo, but $d$-fenfluramine and its bioactive metabolite $d$-norfenfluramine exhibit significantly larger SERT-mediated currents when compared with phenylpiperazines, and only fenfluramines produce long-term 5-HT depletions. Collectively, these findings point to the involvement of SERT-mediated ionic currents in the mechanism of 5 -HT depletion produced by SERT substrates.

\section{MATERIALS AND METHODS}

\section{Drugs and Reagents}

( \pm )-N-ethyl-1-[3-(trifluoromethyl)phenyl]propan-2-amine hydrochloride (fenfluramine, MW 267.7), (+)-N-ethyl-1[3-(trifluoromethyl)phenyl]propan-2-amine hydrochloride (d-fenfluramine, MW 267.7) and (+)-1-[3-(trifluoromethyl)phenyl]propan-2-amine hydrochloride ( $d$-norfenfluramine, MW 239.7) were obtained from the NIDA Drug Supply Program (Rockville, MD, USA). 1-(3-Chlorophenyl)piperazine dihydrochloride (mCPP, MW 269.7), 1-(3trifluoromethylphenyl)piperazine hydrochloride (TFMPP, MW 266.7), fluoxetine, and pargyline were purchased from Sigma Chemical (St Louis, MO, USA). Pentobarbital sodium was obtained from the NIDA IRP Pharmacy (Baltimore, MD, USA). $\left[{ }^{3} \mathrm{H}\right] 5-\mathrm{HT}$ and $\left[{ }^{3} \mathrm{H}\right] \mathrm{DA}$ were purchased from Dupont New England Nuclear (Boston, MA, USA). All reagents, buffer salts and chemicals were obtained from Sigma Chemical unless otherwise noted. Plasmids encoding human SERT were a generous gift of Dr Susan G Amara.

\section{Animals and Housing}

Male Sprague-Dawley rats (Charles River, Wilmington, MA, USA) weighing 300-400 g were housed in standard conditions (lights on from 0700 to 1900 hours) with food and water freely available. Rats were maintained in facilities fully accredited by the Association for Assessment and Accreditation of Laboratory Animal Care (AAALAC), and experiments were performed in accordance with the Institutional Care and Use Committee of the NIDA IRP. Xenopus laevis frogs (Nasco, Fort Atkinson, WI, USA) were kept in aquariums on a strict 12-h light:dark schedule with food available once weekly.

\section{In Vivo Microdialysis in Rat Nucleus Accumbens}

In vivo microdialysis procedures were carried out as previously described (Baumann et al, 2012). Briefly, male rats were surgically prepared with jugular catheters and intracerebral guide cannulae aimed at the nucleus accumbens ( $\mathrm{AP}+1.6 \mathrm{~mm}$, $\mathrm{ML}-1.7 \mathrm{~mm}$ relative to bregma; $-6.2 \mathrm{~mm}$ relative to dura). After a 7 - to 10 -day recovery period, catheters were attached to extension tubes and $0.5 \times 2 \mathrm{~mm}$ microdialysis probes (CMA/12, Harvard Apparatus, Holliston, MA, USA) were inserted into guide cannulae. Ringers' solution was perfused through the probe at $0.5 \mu \mathrm{l} / \mathrm{min}$ overnight. On the following morning, dialysate samples were collected at 20-min intervals and drug treatments were given after three baseline samples were obtained. Rats received four sequential i.p. injections (one injection every $2 \mathrm{~h}$ for a total of four doses). The dose was $6 \mathrm{mg} / \mathrm{kg}$ for all drugs, and dialysate samples were collected throughout the dosing period (ie, for $8 \mathrm{~h}$ after the first injection). Levels of 5-HT and dopamine were quantified using high-pressure liquid chromatography coupled to electrochemical detection (HPLC-EC; Baumann et al, 2012). Dialysate samples were injected onto a microbore HPLC column coupled to an EC detector with a glassy carbon electrode set at $+650 \mathrm{mV}$ relative to $\mathrm{Ag} / \mathrm{AgCl}$ reference. Mobile phase was pumped at $60 \mu \mathrm{l} / \mathrm{min}$. Chromatographic data were exported to a Millenium software 
system (Waters, Milford, MA, USA) for peak identification, integration, and analysis.

\section{Determination of Post-Mortem Tissue Levels of Monoamines}

Two weeks after undergoing microdialysis testing, rats were decapitated and brains were quickly bisected on ice. The hemisphere containing the microdialysis guide cannulae was frozen on dry ice and stored at $-80^{\circ} \mathrm{C}$. Sections were cut on a cryostat and examined to determine the placement of the probe tip in the nucleus accumbens. The remaining hemisphere was rapidly dissected on ice to yield frontal cortex, dorsal striatum (containing caudate nucleus), and ventral striatum (containing nucleus accumbens). Dissected tissue was transferred to cryovials, frozen on dry ice, and stored at $-80^{\circ} \mathrm{C}$ until it was analyzed for tissue monoamines and their metabolites using HPLC-EC detection as previously described (Baumann et al, 2001).

\section{In Vitro $\left[{ }^{3} \mathrm{H}\right] 5-\mathrm{HT}$ and $\left[{ }^{3} \mathrm{H}\right]$ dopamine Release Assays}

In vitro release assays were carried out as previously described (Rothman et al, 2001). Briefly, crude synaptosomes were prepared from rat brain minus cerebellum and caudate for $\left[{ }^{3} \mathrm{H}\right] 5 \mathrm{HT}$ release or from rat caudate for $\left[{ }^{3} \mathrm{H}\right]$ dopamine release. Tissue was homogenized in ice-cold $10 \%$ sucrose containing $1 \mu \mathrm{M}$ reserpine. Nomifensine $(100 \mathrm{nM})$ and GBR12935 (100 nM) were added to preparations used for $\left[{ }^{3} \mathrm{H}\right] 5 \mathrm{HT}$ release assays to prevent $\left[{ }^{3} \mathrm{H}\right] 5 \mathrm{HT}$ uptake into norepinephrine and dopamine nerve terminals. Homogenates were centrifuged at $1000 \times g$ for $10 \mathrm{~min}$ at $4{ }^{\circ} \mathrm{C}$ and the supernatants (synaptosomes) were retained on ice. Synaptosomes were incubated to steady state at $25^{\circ} \mathrm{C}$ with $5 \mathrm{nM}\left[{ }^{3} \mathrm{H}\right] 5 \mathrm{HT}(60 \mathrm{~min})$ or $5 \mathrm{nM}\left[{ }^{3} \mathrm{H}\right]$ dopamine $(30 \mathrm{~min})$ diluted in Krebs buffer containing $1 \mu \mathrm{M}$ reserpine. Release assays were initiated by adding $900 \mu \mathrm{l}$ of the preloaded synaptosomes to test tubes that contained $100 \mu \mathrm{l}$ of test drug made up in phosphate buffer with $1 \mathrm{mg} / \mathrm{ml}$ BSA. Release stimulation curves were generated by incubating preloaded synaptosomes with 8-10 concentrations of $d$-fenfluramine, $d$-norfenfluramine, mCPP, or TFMPP ( $1 \mathrm{nM}$ to $100 \mu \mathrm{M})$. For the fluoxetine reversal experiments, tubes contained $10 \mathrm{nM}$ fluoxetine in the presence of releasing drug. After $5 \mathrm{~min}$, the release reaction was terminated by dilution with $4 \mathrm{ml}$ of wash buffer at $25^{\circ} \mathrm{C}$, followed by rapid vacuum filtration over Whatman GF/B filters. The filters were rinsed twice with $4 \mathrm{ml}$ wash buffer, and retained tritium was counted by a liquid scintillation counter at $40 \%$ efficiency after an overnight extraction in Cytoscint.

\section{Electrophysiological Recordings in Xenopus laevis Oocytes}

Xenopus laevis frogs were anesthetized with ethyl 3aminobenzoate methanesulfonate $\left(2 \mathrm{mg} / \mathrm{ml}\right.$ in $\left.\mathrm{H}_{2} \mathrm{O}\right)$. The frog was decapitated and the ovarian lobes were removed and transferred to sterile $\mathrm{Ca}^{2+}$-free OR2 solution $(82.5 \mathrm{mM} \mathrm{NaCl}$, $2.5 \mathrm{mM} \mathrm{KCl}, 2 \mathrm{mM} \mathrm{MgCl}, 10 \mathrm{mM}$ HEPES, $\mathrm{pH}$ adjusted to 7.4 with $\mathrm{NaOH}$ ). The lobes were manually reduced to groups of 5-10 oocytes and incubated in OR2, containing $1 \mathrm{mg} / \mathrm{ml}$ collagenase from Clostridium histolyticum (Sigma Chemical).
45-60 min of incubation at $18^{\circ} \mathrm{C}$ were sufficient to digest and remove the follicular layer. Oocytes were then selected and transferred to a Ringer-solution $(100 \mathrm{mM} \mathrm{NaCl}, 2 \mathrm{mM} \mathrm{KCl}$, $1.8 \mathrm{mM} \mathrm{CaCl}_{2}, 1 \mathrm{mM} \mathrm{MgCl}, 5 \mathrm{mM}$ Hepes, $\mathrm{pH}$ adjusted to 7.6 with $\mathrm{NaOH})$. Oocytes were kept at $18^{\circ} \mathrm{C}$ for a minimum of $2 \mathrm{~h}$ before injection. Injected oocytes were kept for 6-9 days at $18{ }^{\circ} \mathrm{C}$ in a Ringer solution containing $2.5 \mathrm{mM} \mathrm{Na}^{+}$pyruvate, $100 \mu \mathrm{g} / \mathrm{ml}$ penicillin, and $100 \mu \mathrm{g} / \mathrm{ml}$ streptomycin. Solutions were changed daily. Electrophysiology experiments were performed as described earlier (Bulling et al, 2012). A plasmid encoding hSERT was linearized and transcribed into RNA with a T7 RNA polymerase Kit mMessage mMachine (Ambion, Life Technologies, Grand Island, NY, USA). A total of $5 \mathrm{ng}$ cRNA was microinjected into each oocyte. Electrophysiological recordings were performed 6-9 days following injection at $18{ }^{\circ} \mathrm{C}$. A CA-1B high performance oocyte clamp was used for the measurements. The recorded signal was digitized with a Digidata 13222A (Axon Instruments, Molecular Devices, Sunnyvale, CA, USA). An Intel PC running pCLAMP 9.2 (Axon Instruments) was used for acquisition. Borosilicate glass capillaries were pulled to a final resistance of 0.4-1.2 megaohm and filled with $3 \mathrm{M} \mathrm{KCl}$. Oocytes were impaled and the membrane potential was clamped to a holding potential of $-60 \mathrm{mV}$. For continuous superfusion with ND100 solution ( $100 \mathrm{mM} \mathrm{NaCl}, 2 \mathrm{mM} \mathrm{KCl}, 1 \mathrm{~mm} \mathrm{CaCl}$, $1 \mathrm{mM} \mathrm{MgCl}, 10 \mathrm{mM}$ HEPES, $\mathrm{pH}$ adjusted to 7.4 with $\mathrm{NaOH}$ ), a gravity-driven superfusion system was used. Recordings were started after a stable current baseline was established. The current was sampled with $100 \mathrm{~Hz}$ and low pass filtered with $20 \mathrm{~Hz}$.

\section{Data Analysis and Statistics}

For the microdialysis experiments, the first three samples collected were considered baseline samples and all subsequent monoamine measures were expressed as a percentage of the mean of this baseline. Effects of drugs on dialysate 5-HT and dopamine were evaluated using two-way ANOVA (treatment $\times$ time) followed by Bonferroni post hoc tests at specific time points after drug injection. The post-mortem tissue data were analyzed by one-way ANOVA (treatment) to compare drug effects with saline-injected controls. When significant $\mathrm{F}$ values were obtained, Newman-Keuls' post hoc tests were performed. The relationship between post-mortem tissue 5-HT and dialysate concentrations of 5-HT were assessed using Pearson's correlation coefficient. For the release assays, the data from three experiments were fit to a doseresponse curve equation, and $\mathrm{EC}_{50}$ values were calculated using Graph Pad Prism. To determine apparent Ki for fluoxetine, data were analyzed by MLAB-PC (Civilized Software, Bethesda, MD, USA) as described elsewhere (Rothman et al, 2001). For transporter-mediated currents, the comparison of the maximum currents across drugs was analyzed by one-way ANOVA with Tukey's post hoc test. $P<0.05$ was chosen as the minimum criterion for statistical significance.

\section{RESULTS}

Fenfluramines and Piperazines Increase Dialysate 5-HT in Intact Brain

In the first set of experiments, we monitored extracellular concentrations of 5-HT and dopamine in the nucleus 

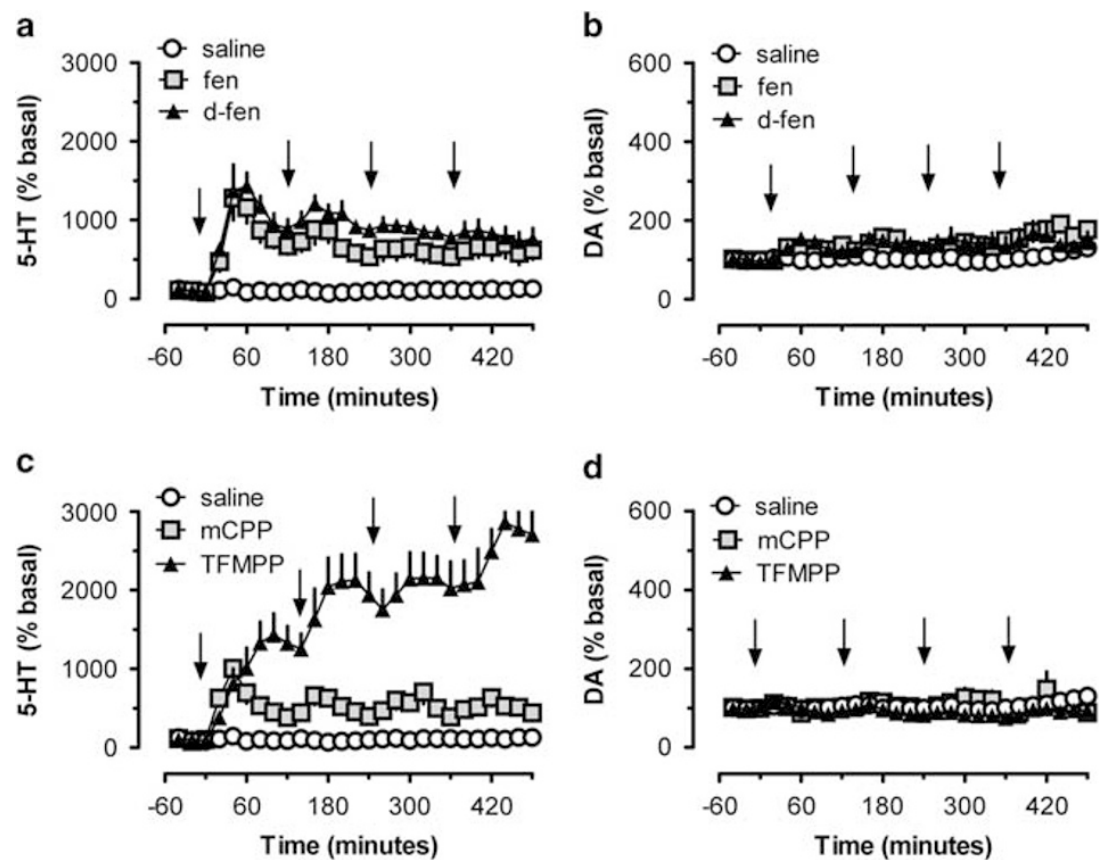

Figure I Effects of repeated i.p. administrations of saline, fenfluramine (fen), d-fenfluramine (d-fen), mCPP, and TFMPP on extracellular 5-HT and dopamine (DA) in rats undergoing microdialysis in nucleus accumbens. Panel a depicts the effects of fen, $\mathrm{d}$-fen, and saline on dialysate 5-HT, whereas panel b shows dialysate dopamine. Panel c depicts effects of mCPP, TFMPP, and saline on dialysate 5-HT, whereas panel d shows dialysate dopamine. Arrows indicate time of injections. Data are mean \pm SEM expressed as \% baseline for $N=5$ rats per group.

accumbens of rats that received four sequential drug treatments $(6 \mathrm{mg} / \mathrm{kg}$, i.p.). The dosing regimen was chosen based on pilot studies and previous findings that showed similar doses of $d$-fenfluramine decrease brain tissue 5-HT at 2 weeks after injection (Baumann et al, 2001). The data depicted in Figure 1a show that both fenfluramine treatments significantly affected extracellular 5-HT $\left(\mathrm{F}_{2,26}=349.7 ; \quad p<0.0001\right)$ and there was a significant treatment $\times$ time interaction $\left(\mathrm{F}_{2,52}=2.74 ; p<0.001\right)$. The first dose of fenfluramine and $d$-fenfluramine increased extracellular 5 -HT by about 12 -fold (ie, $1200 \%$ of basal), followed by a gradual decline. The next dose caused a smaller increase in extracellular 5-HT, whereas subsequent doses failed to further elevate 5-HT levels. Nevertheless, the overall effect of drug administration was to cause persistent and significant elevation of extracellular 5-HT in the range of $500-800 \%$ for the duration of sampling $(p<0.05$, Bonferroni). Fenfluramine treatments also influenced dopamine $\left(\mathrm{F}_{2,26}=38 ; p<0.001\right)$, but in this case, there was no treatment $\times$ time interaction $\left(\mathrm{F}_{2,52}=0.745\right.$; NS). Although dopamine levels were elevated to about $150 \%$ of basal for both drugs, post hoc tests revealed this increase did not differ from saline at any time point (Figure $1 b$ ).

The data in Figure 1c demonstrate that phenylpiperazine treatments significantly affected extracellular 5-HT $\left(\mathrm{F}_{2,26}=596.3 ; \quad p<0.0001\right)$ and there was a significant treatment $\times$ time interaction $\left(\mathrm{F}_{2,52}=7.09 ; p<0.001\right)$. The pattern of 5-HT response produced by $\mathrm{mCPP}$ mimicked the effects of fenfluramines. Specifically, the first dose of mCPP increased extracellular 5 -HT by about $1000 \%$ of basal, and subsequent doses maintained dialysate $5-\mathrm{HT}$ at about $500 \%$, significantly above control for the duration of sampling $(p<0.05$, Bonferroni). The first dose of TFMPP increased extracellular 5-HT to higher levels than the other agents (about $1400 \%$ of basal), and subsequent doses continued to increase 5-HT to a peak level of about 30-fold above basal. The robust elevations in dialysate 5-HT induced by TFMPP were significantly greater than those induced by $\mathrm{mCPP}$ at all points after the second, third, and fourth injections $(p<0.05)$. Piperazine treatments influenced dopamine $\left(\mathrm{F}_{2,26}=9.64 ; p<0.001\right)$, but there was no treatment $\times$ time interaction $\left(\mathrm{F}_{2,52}=0.70 ; \mathrm{NS}\right)$. $\mathrm{mCPP}$ produced modest elevations in dopamine $(150 \%$ basal $)$ whereas TFMPP actually decreased dopamine ( $80 \%$ basal) at later time points. Post hoc tests revealed that changes in dialysate dopamine were not different from saline at any time point (Figure 1d).

\section{Only Fenfluramines Cause Persistent Depletion of Brain 5-HT}

Two weeks after the microdialysis experiments, rats were killed and brains were removed for analysis of post-mortem tissue 5-HT, 5-hydroxyindoleacetic acid, dopamine and 3,4dihydroxyphenylacetic acid by HPLC with electrochemical detection (Baumann et al, 2001). As reported in Figure 2, repeated drug treatments had a significant effect on tissue concentrations of 5-HT $\left(\mathrm{F}_{4,20}=17.09 ; p<0.0001\right)$ but not DA $\left(\mathrm{F}_{4,20}=0.678 ; \mathrm{NS}\right)$. In particular, fenfluramines significantly depleted tissue levels of 5-HT in the nucleus accumbens $(p<0.05$, Newman-Keuls; Figure 2a), whereas mCPP and TFMPP did not (Figure 2c). Similar results were observed in tissue from cortex and caudate nucleus (data not shown). Tissue concentrations of 5-HT in the accumbens (ng/100 mg tissue) were negatively correlated with mean extracellular 5-HT (pg/ $\mu \mathrm{l})$ measured during microdialysis for rats exposed to fenfluramines $(r=-0.7975$, 

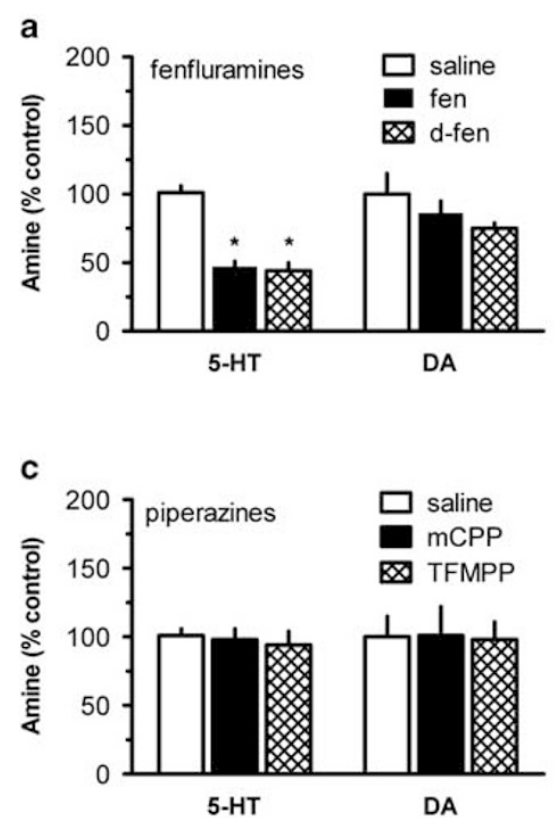

b
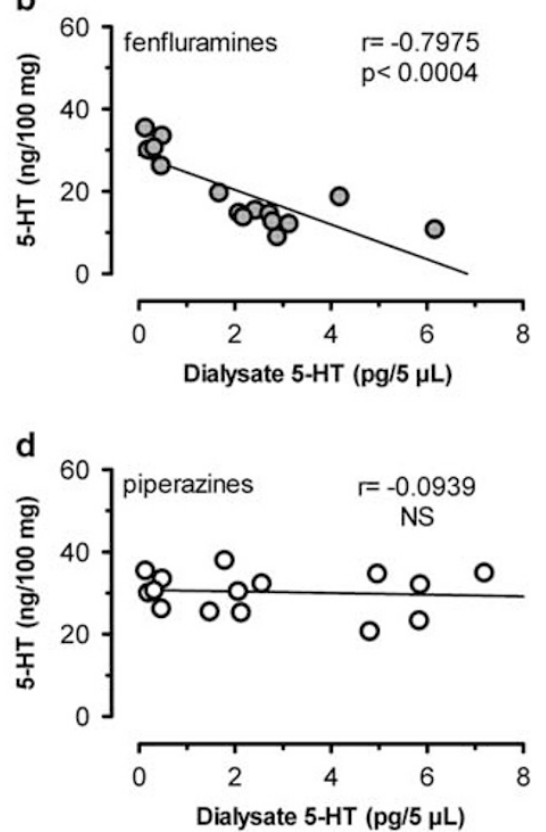

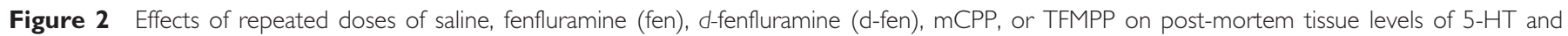

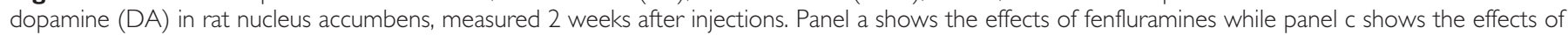

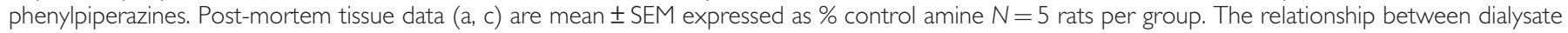

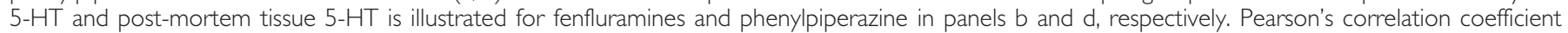

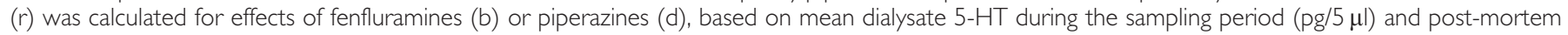
tissue levels of $5-\mathrm{HT}(\mathrm{ng} / \mathrm{l} 00 \mathrm{mg})$ for individual subjects. $N=15$ rats per plot.

$p<0.0004)$, but this relationship was not apparent for rats exposed to piperazines ( $r=-0.0939$, NS; Figures $2 \mathrm{~b}$ and $\mathrm{d}$ ).

\section{$d$-Fenfluramine, $d$-Norfenfluramine, and Piperazines are Transporter Substrates}

We next characterized the interaction of SERT substrates with transporters in vitro using a synaptosomal preparation from rat brain. In these experiments, we compared the effects of $d$-fenfluramine, mCPP, and TFMPP, but also included the metabolite $d$-norfenfluramine, as this metabolite has been implicated in the 5-HT depletion produced by $d$-fenfluramine observed in vivo (Caccia et al, 1993; Johnson and Nichols, 1990). Consistent with our previous findings (Rothman et al, 2001), $d$-fenfluramine and $d$-norfenfluramine evoked the release of preloaded $\left[{ }^{3} \mathrm{H}\right] 5-\mathrm{HT}$ from synaptosomes. Dose-response curves were shifted significantly to the right by co-incubation with the SERT uptake inhibitor fluoxetine $(p<0.05)$, indicating that both compounds are substrates for SERT (Figures $3 a$ and $b$ ). Similar data were obtained with $\mathrm{mCPP}$ and TFMPP (Figures $3 \mathrm{c}$ and d), indicating that these agents are also SERT substrates. As reported in Table 1 , fenfluramine, $d$-fenfluramine, and mCPP had similar $\mathrm{EC}_{50}$ values for releasing $\left[{ }^{3} \mathrm{H}\right] 5-\mathrm{HT}$ $(\sim 50-70 \mathrm{nM})$ whereas TFMPP was somewhat less potent with an $\mathrm{EC}_{50}$ value of $190 \mathrm{nM}$. The apparent Ki of fluoxetine for SERT ranged from $4.3 \mathrm{nM}$ for $d$-fenfluramine to $8.7 \mathrm{nM}$ for TFMPP. It is important to note that $d$-fenfluramine, $d$-norfenfluramine, and the phenylpiperazines were fully efficacious in their ability to induce 5-HT release (ie, $\left.\mathrm{E}_{\max }=100 \%\right)$. By contrast, $d$-fenfluramine, $\mathrm{mCPP}$, and
TFMPP were inactive at releasing $\left[{ }^{3} \mathrm{H}\right]$ dopamine when tested at concentrations up to $10 \mu \mathrm{M}$ (data not shown).

\section{Fenfluramines Evoke Larger SERT-Mediated Currents than Piperazines}

Once it was determined that all test compounds were efficacious SERT substrates, the propensity for the drugs to elicit SERT-mediated currents was examined. Transporter currents can be elicited by amphetamine and nonamphetamine substrates, including the physiological substrate 5-HT (Hilber et al, 2005; Mager et al, 1994; Schicker et al, 2012). In these experiments, we compared the effects of $d$-fenfluramine, $d$-norfenfluramine, mCPP, and TFMPP, but also included methylthioamphetamine (MTA) because we have shown previously that this compound is a nontoxic SERT substrate that induces relatively small inward currents (Gobbi et al, 2008). A saturating concentration of $10 \mu \mathrm{M}$ 5-HT was used as a reference point (Hilber et al, 2005), and increasing concentrations of each of the compounds were tested (Figures $4 \mathrm{a}-\mathrm{e}$ ). All drugs elicited currents in a dosedependent manner, and consistently showed a progressive decline of the current with higher concentrations. This type of bell-shaped concentration-response curve has been described in an earlier study (Gobbi et al, 2008). Briefly, currents evoked by PCA reach a maximum between 10 and $30 \mu \mathrm{M}$ in hSERT-expressing Xenopus laevis oocytes. These currents decline at concentrations above $30 \mu \mathrm{M}$ and almost completely vanish at concentrations of $300 \mu \mathrm{M}$. A likely explanation for the decline of currents at high doses is the inhibition of current by accumulated intracellular drug molecules; this hypothesis is supported by the findings of 

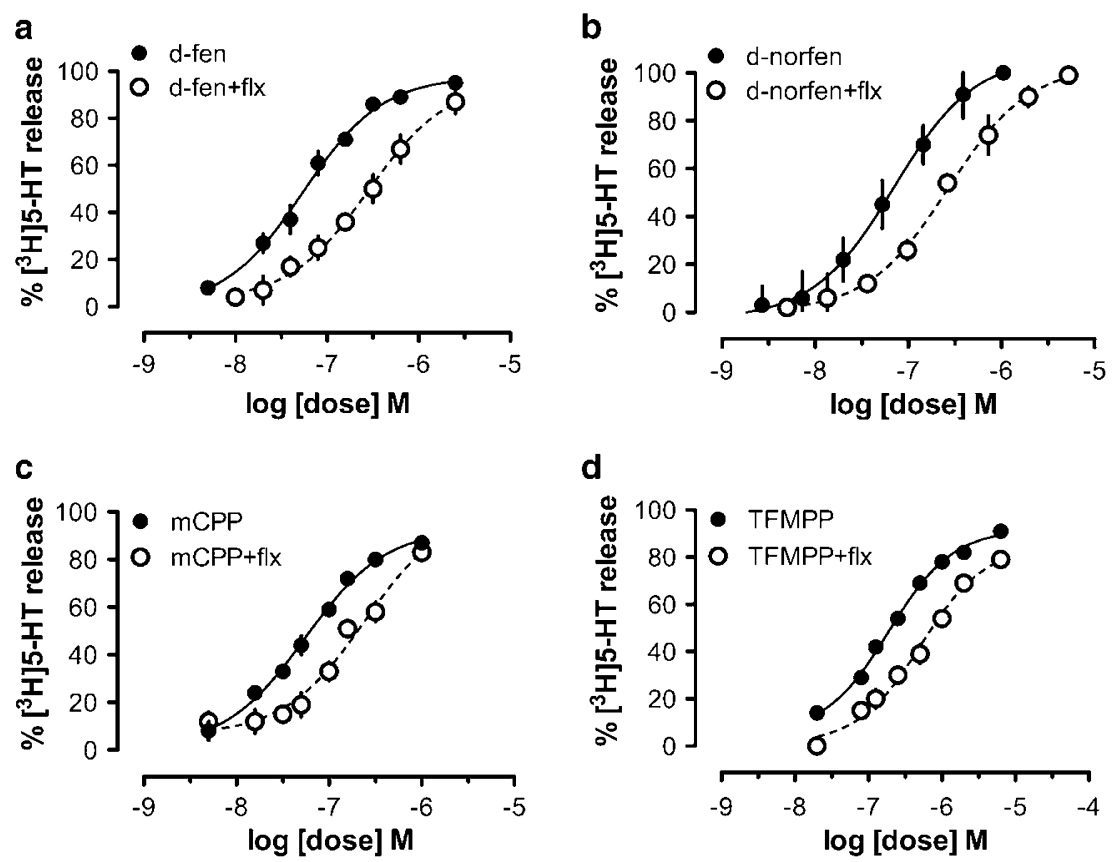

Figure 3 Release of preloaded $\left[{ }^{3} \mathrm{H}\right] 5-\mathrm{HT}$ from rat brain synaptosomes evoked by $d$-fenfluramine (d-fen), d-norfenfluramine (d-norfen), mCPP, and TFMPP. Drug-induced $\left.{ }^{3} \mathrm{H}\right]-5-H T$ release was measured in the presence or absence of $10 \mathrm{nM}$ fluoxetine for d-fen (a), d-norfen (b), mCPP (c), and TFMPP (d). Data are mean \pm SD for $N=3$ separate experiments.

Table I In Vitro Release Data for Test Compounds

\begin{tabular}{|c|c|c|c|}
\hline Treatment & $\begin{array}{l}\left.{ }^{3} \mathrm{H}\right] 5-\mathrm{HT} \\
\mathrm{EC}_{50}(\mathrm{nM})\end{array}$ & $\begin{array}{c}\text { Fluoxetine } \\
\text { apparent } K_{\mathbf{l}} \\
(\mathrm{nM})\end{array}$ & $\begin{array}{c}{\left[{ }^{3} \mathrm{H}\right] \text { dopamine }} \\
\mathrm{EC}_{50}(\mathrm{nM})\end{array}$ \\
\hline$d$-Fenfluramine & $54 \pm 4$ & 4.3 & $>10000$ \\
\hline $\begin{array}{l}\text { d-Fenfluramine }+10 \mathrm{nM} \\
\text { fluoxetine }\end{array}$ & $279 \pm 29$ & & \\
\hline$d$-Norfen & $70 \pm 9$ & 6.3 & ND \\
\hline$d$-Norfen $+10 \mathrm{nM}$ fluoxetine & $266 \pm 25$ & & \\
\hline $\mathrm{mCPP}$ & $55 \pm 4$ & 5.0 & $>10000$ \\
\hline $\mathrm{mCPP}+10 \mathrm{nM}$ fluoxetine & $240 \pm 31$ & & \\
\hline TFMPP & $190 \pm 12$ & 8.7 & $>10000$ \\
\hline TFMPP + $10 \mathrm{nM}$ fluoxetine & $519 \pm 47$ & & \\
\hline
\end{tabular}

Effects of drugs on $\left[{ }^{3} \mathrm{H}\right] 5-\mathrm{HT}$ and $\left[{ }^{3} \mathrm{H}\right]$ dopamine release from rat brain synaptosomes as outlined in Materials and Methods section. Data are expressed as mean $\pm \mathrm{SD}$ for three experiments performed in triplicate. Dopamine release for $d$-norfenfluramine was not determined (ND).

Adams and Defelice (2003). Thus, it is very likely that the drugs examined in this study reached high enough intracellular concentration to profoundly inhibit substrateinduced currents.

A comparison of the raw current traces elicited by the five test compounds revealed inwardly directed currents for $d$-fenfluramine and $d$-norfenfluramine that were almost as high as the 5-HT-induced current (Figures $4 \mathrm{a}$ and b). By contrast, the piperazine drugs $\mathrm{MCPP}$ and TFMPP elicited about half the 5-HT-induced current (Figures $4 \mathrm{c}$ and d). Similarly, MTA elicited a comparably small current (Figure 4e). Next, we analyzed all current data and compared the resulting concentration-response curves (Figure 5a). At low concentrations of the SERT substrates (up to $1 \mu \mathrm{M}$ ), currents were indistinguishable. However, the picture changed at concentrations $>3 \mu \mathrm{M}$, where $d$ fenfluramine and $d$-norfenfluramine induced a significantly greater magnitude of current than the piperazines or MTA. It is noteworthy that $\mathrm{EC}_{50}$ values for the induction of currents were comparable among most of the compounds (Table 2), and this agrees with the similar $\mathrm{EC}_{50}$ values obtained in the synaptosome release experiments (Table 1). The only drug that misses this nice correlation is $d$ norfenfluramine, which elicits current at much higher concentrations (at around $10 \mu \mathrm{M}$ ) when compared with the $\mathrm{EC}_{50}$ values obtained in the synaptosome release.

We next performed a comparison of all the test compounds in single oocytes; we used the concentrations where the maximum current was induced in the concentration-response curves. Although the piperazine compounds reached the maximum current at $3 \mu \mathrm{M}$, for $d$-fenfluramine $10 \mu \mathrm{M}$, and for $d$-norfenfluramine $100 \mu \mathrm{M}$ was necessary to reach peak conductance (Figure 5a). Finally, a comparison of the maximally induced currents revealed significant differences between drugs $\left(\mathrm{F}_{3,19}=79.11 ; p<0.001\right)$, such that $d$-fenfluramine and $d$-norfenfluramine elicit significantly greater currents than either of the phenylpiperazine compounds or MTA $(p<0.05$, one-way ANOVA). Interestingly, we observed a transient current increase upon removal of amphetamine concentrations that had first led to a current decrease. This suggests that current activation and current inhibition might be independent processes.

\section{DISCUSSION}

It is well established that fenfluramine and other ringsubstituted amphetamines, such as MDMA and PCA, cause 
long-term depletion of brain 5-HT in rats (McCann et al, 1997; Rothman and Baumann, 2002; Xie et al, 2006), but the underlying mechanisms responsible for this effect are not

a
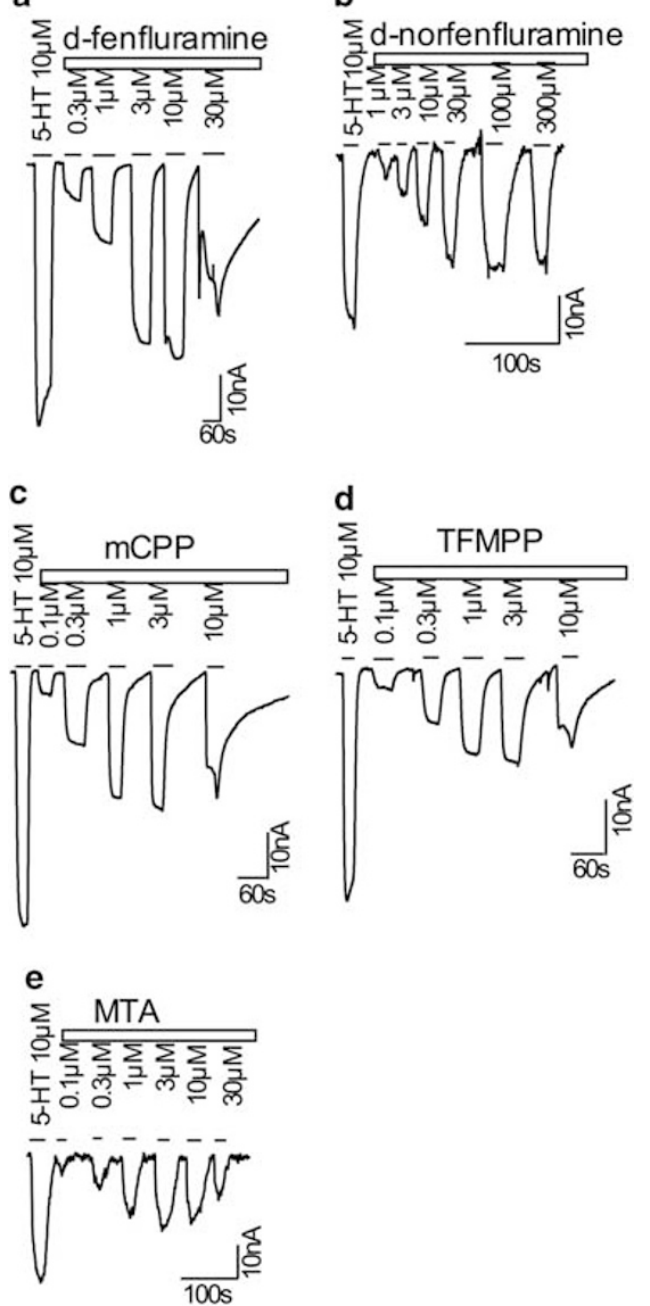

Figure 4 SERT-generated currents in Xenopus oocytes induced by increasing concentrations of $d$-fenfluramine, d-norfenfluramine, mCPP, TFMPP, or MTA in comparison with the physiological substrate 5-HT (IO $\mu \mathrm{M})$. Sample traces are shown in panels a-e, and drug concentrations are given in $\mu \mathrm{M}$. clear. Fenfluramine, MDMA, and PCA are SERT substrates that evoke non-exocytotic release of 5-HT by reversing the normal direction of transporter flux (Berger et al, 1992; Rothman and Baumann, 2002; Schuldiner et al, 1993). Thus, a reasonable hypothesis is that acute 5-HT-releasing effects of amphetamine analogs are responsible for persistent 5-HT deficits produced by these drugs (Schwartz et al, 1989; Series et al, 1994). According to one version of this hypothesis, supraphysiological elevations in extracellular 5-HT promote the formation of toxic 5-HT metabolites (eg, 5,6-dihydroxytryptamine) that generate free radicals and cause cellular damage (Cadet and Brannock, 1998; Seiden and Sabol, 1996; Wrona and Dryhurst, 2001).

Considerable data support a role for free radicals in the development of MDMA-induced 5-HT deficits (Jones et al, 2005; Lyles and Cadet, 2003), but this type of mechanism may not explain persistent effects of fenfluramines (Colado et al, 1997; Murray et al, 1996). Importantly, several lines of evidence indicate that substrate-induced increases in extracellular 5-HT can be dissociated from long-term 5HT depletions. More than 20 years ago, the Nichols group identified analogs of MDMA and PCA that are potent and selective 5-HT releasers in vitro but do not cause 5-HT depletion in vivo (Johnson et al, 1990, 1991; Nichols et al, 1990). We reported previously that mCPP increases extracellular 5-HT as effectively as fenfluramine, but does not cause a persistent decrease in brain 5-HT (Baumann et al, 2001). On the basis of these collective findings, it was

Table 2 EC $_{50}$ Data for Current Induction by Test Compounds

\begin{tabular}{lccc}
\hline Drug & EC $_{\mathbf{5 0}}(\boldsymbol{\mu M})$ & $\begin{array}{c}\mathbf{9 5 \%} \text { Confidence } \\
\text { interval }\end{array}$ & $\mathbf{n}$ \\
\hline d-Fenfluramine & 1.2 & $0.42-2.43$ & 7 \\
d-Norfenfluramine & 10.2 & $1.22-2.24$ & 7 \\
mCPP & 1.94 & $1.77-2.12$ & 5 \\
TFMPP & 2.43 & $1.74-3.4$ & 5 \\
MTA & 1.27 & $0.2-2.21$ & 6
\end{tabular}

Effects of drugs on the generation of current, measured in hSERT-expressing Xenopus laevis oocytes as outlined in the Materials and methods section. Data are expressed as mean of five to seven experiments performed in individual oocytes.

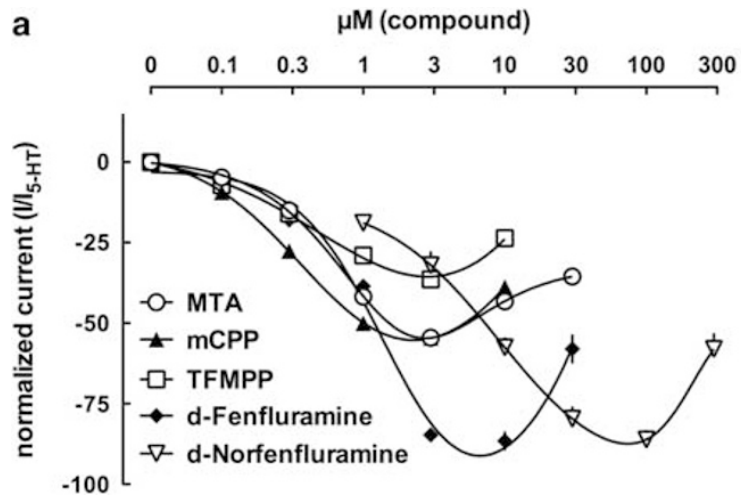

b

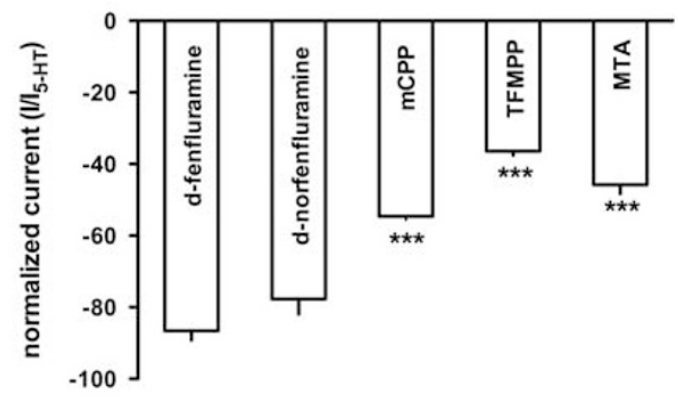

Figure 5 (a) Concentration-response curves, pooled from different oocytes and (b) comparison of the maximal current ( $\left.C_{\max }\right)$ for $d$-fenfluramine, $d$ norfenfluramine, mCPP, TFMPP, and MTA compared in the same oocyte. Maximal current for $d$-fenfluramine was measured at $10 \mu M$ and for $d$ norfenfluramine at $100 \mu \mathrm{M}$, whereas maximal current for mCPP, TFMPP, and MTA was measured at $3 \mu \mathrm{M}$. Statistical analysis revealed significant differences at a level of $p<0.0$ I (****). 
suggested that being a SERT substrate is necessary, but not sufficient, to produce long-term 5-HT depletion. Subsequent reports have identified and characterized a number of structurally distinct SERT substrates that have a reduced propensity for causing 5-HT depletion (Baumann et al, 2012; Gobbi et al, 2008; Rothman et al, 2005).

A major weakness of the above-mentioned studies is that no experiments tested the effects of SERT substrates on in vivo 5-HT release and long-term 5-HT depletion in the same subjects. This type of within-subjects investigation is essential before concluding that a SERT substrate is not neurotoxic. Extrapolating in vitro drug effects to in vivo conditions is complicated by a variety of factors including drug absorption, metabolism, and brain penetrance. To address such issues, we used microdialysis sampling to measure extracellular 5-HT and dopamine in the brains of rats, during exposure to repeated injections of fenfluramines or phenylpiperazines. The same rats were examined 2 weeks later to assess depletion of brain tissue monoamines. Administration of fenfluramine, $d$-fenfluramine, and mCPP resulted in sustained increases in dialysate 5-HT that ranged from five- to eightfold higher than baseline (Figures 1a-c). By contrast, each of the four injections of TFMPP produced a step-wise increase in extracellular 5-HT that reached levels 25-times higher than normal (Figure 1d). The present microdialysis results agree with previous findings that show single i.v. injections of fenfluramines or phenylpiperazines increase dialysate 5-HT, but not dopamine, in rat brain (Baumann et al, 2001, 2005). On the other hand, TFMPP is reportedly less potent than $\mathrm{MCPP}$ as a 5 -HT releaser in vivo. Thus, we have no explanation for the large increases in dialysate 5-HT produced by repeated i.p. injections of TFMPP as compared with the other drugs. One possibility is that TFMPP is metabolized by hepatic mechanisms to a compound that is a powerful SERT substrate (Staack et al, 2004), and this proposal warrants investigation.

Although fenfluramine, $d$-fenfluramine, and the phenylpiperazines produced large sustained elevations in extracellular 5-HT, only the fenfluramines caused 5-HT depletions (Figure 2). Interestingly, post-mortem tissue concentrations of 5-HT were negatively correlated with extracellular concentrations of 5-HT measured during dialysis sampling in rats exposed to fenfluramines, but not in rats exposed to phenylpiperazines. These data demonstrate a key difference between fenfluramine and phenylpiperazine SERT substrates, and provide compelling evidence that increases in extracellular 5-HT may not underlie long-term 5-HT depletion. One simple interpretation of the data is that SERT proteins act as 'gateways' to allow the accumulation of SERT substrates or their bioactive metabolites into nerve cells, thereby promoting subsequent intracellular damage (Jones et al, 2005; Rothman et al, 1999). This hypothesis is consistent with the observation that SERT blockers like fluoxetine can prevent the long-term 5-HT depletion produced high-dose fenfluramines (Clineschmidt et al, 1978; Steranka and Sanders-Bush, 1979).

If one assumes that the gateway hypothesis is tenable, then a fundamental question arises: what properties distinguish SERT substrates that cause 5-HT depletion from those that do not? As a means to compare the molecular mechanism of action for $d$-fenfluramine and phenylpiperazines, we examined the ability of the drugs to evoke release of preloaded $\left[{ }^{3} \mathrm{H}\right] 5-\mathrm{HT}$ and $\left[{ }^{3} \mathrm{H}\right]$ dopamine in rat brain synaptosomes. In these experiments, we also included the $N$-deethylated metabolite of $d$-fenfluramine, $d$-norfenfluramine, because this compound has been implicated in the 5-HT deficits produced by $d$-fenfluramine administration in rats (Caccia et al, 1993; Johnson and Nichols, 1990). Our release experiments clearly demonstrate that $d$-fenfluramine, $d$-norfenfluramine, MCPP, and TFMPP are fully efficacious in their ability to release $\left[{ }^{3} \mathrm{H}\right] 5-\mathrm{HT}$ (Figures $3 \mathrm{a}-\mathrm{d}$ ), with minimal effects on release of $\left[{ }^{3} \mathrm{H}\right]$ dopamine. Furthermore, co-incubation with fluoxetine caused parallel right-ward shifts in the 5-HT release curves for all drugs. These results provide decisive evidence that all of the compounds are selective SERT substrates. This fact is well accepted for $d$-fenfluramine and $d$-norfenfluramine (Rothman et al, 2003), but less so for phenylpiperazines. Pettibone and Williams (1984) were the first to demonstrate that phenylpiperazines like $\mathrm{MCPP}$ and TFMPP induce the release of preloaded $\left[{ }^{3} \mathrm{H}\right] 5-\mathrm{HT}$ from rat brain tissue in vitro. Auerbach et al (1990) subsequently showed that TFMPP evokes the release of endogenous 5-HT from rat hippocampal slices by a fluoxetine-sensitive mechanism. The present in vitro findings add to the growing body of evidence showing that mCPP and TFMPP are potent and selective SERT substrates, and this feature contributes prominently to their in vivo mechanism of action (Auerbach et al, 1990; Baumann et al, 1993, 2005; Eriksson et al, 1999).

Our data from rat brain synaptosomes did not reveal differences between the effects of $d$-fenfluramine and phenylpiperazines. In order to look more closely at possible mechanistic differences between the drugs, we opted to examine transporter-mediated currents in Xenopus oocytes expressing hSERT proteins. We previously examined the pharmacology of MTA and N,N-dimethyl-4-methylthioamphetamine, two SERT substrates with reduced neurotoxic properties. It was found that these amphetamine-related substrates display blunted transporter-mediated currents when compared with PCA (Gobbi et al, 2008). Here, we show that $d$-fenfluramine, $d$-norfenfluramine, mCPP, TFMPP, and MTA all generate SERT-mediated currents in an analogous manner (Figures $4 \mathrm{a}-\mathrm{e}$ ). However, $d$-fenfluramine and $d$-norfenfluramine elicited currents that were up to two times greater in magnitude than those generated by mCPP, TFMPP, or MTA (Figures 5a and b). Importantly, along with others, we have shown that transporter-mediated currents can measurably depolarize cells (Carvelli et al, 2004; Ingram et al, 2002; Meinild et al, 2004; Shi et al, 2000), which may lead to significant changes in the excitability of the cells in nervous tissue (Sulzer, 2011). It seems feasible that sustained increases in SERT activation, coupled with enhanced electrical excitability, could lead to long-term dysregulation of 5-HT neurons. Furthermore, amphetamine-type compounds are notoriously diffusible and easily cross the lipid bilayer. The continuous diffusion of the accumulated $d$-fenfluramine and $d$-norfenfluramine from internal stores, and the subsequent reactivation of transporter-generated current that comes along with it, could be a simple explanation why ongoing depolarization results in profound 5-HT depletion (Rudnick, 2002). However, the question remains as to why the phenylpiperazine drugs are devoid of detrimental effects associated with $d$-fenfluramine? One possibility could be a higher affinity of the 
phenylpiperazines for the internal substrate site on SERT, and this proposal deserves further investigation.

There are a number of caveats that influence the interpretation of our conclusions about the importance of SERT-mediated currents in producing 5-HT deficits. First, as noted in the introduction, fenfluramine and $d$-fenfluramine are selective SERT substrates that do not cause hyperthermia upon systemic administration (Cryan et al, 2000; Malberg and Seiden, 1997). Therefore, the mechanisms responsible for fenfluramine-induced 5-HT deficits may differ from the effects produced by non-selective transporter substrates like PCA and MDMA, which cause robust hyperthermia in rats. Second, elevations in extracellular dopamine, and subsequent formation of catechol metabolites, have been implicated in the mechanism of 5HT toxicity produced by PCA and MDMA (Colado et al, 1997; Murray et al, 1996). Here we show that repeated injections of fenfluramine and $d$-fenfluramine produce small increases in extracellular dopamine, whereas mCPP and TFMPP have no effect or even decrease extracellular dopamine. We cannot rule out the possibility that the dopaminergic effects of fenfluramines contribute to their toxic properties, although this appears unlikely. Finally, there are substantial differences in the receptor pharmacology among fenfluramines and phenylpiperazines that must be considered. $\mathrm{MCPP}$ and TFMPP are known to interact with multiple $5-\mathrm{HT}_{1}$ and $5-\mathrm{HT}_{2}$ receptor subtypes, whereas $d$-fenfluramine and $d$-norfenfluramine are less potent in this regard (Rothman et al, 2000; Schoeffter and Hoyer, 1989). It is feasible that phenylpiperazines could act as agonists, or antagonists, at specific receptor sites, which provide protection against long-term 5-HT depletions. The nonselective 5-HT receptor antagonist metergoline does not alter the acute 5-HT-depleting effect of $d$-fenfluramine, suggesting that post-synaptic 5-HT receptors are not involved in short-term loss of tissue 5-HT (Invernizzi et al, 1982). Selective blockade of $5-\mathrm{HT}_{2 \mathrm{~A}}$ receptors can protect against the long-term 5-HT depletions produced by MDMA (Schmidt et al, 1990; Sprague et al, 1998), but the role of $5-\mathrm{HT}_{2 \mathrm{~A}}$ receptors, and other receptor subtypes, in mediating long-term 5-HT depletions caused by fenfluramines is unexplored and deserves investigation.

In conclusion, our results provide further evidence that 5HT release per se is not the culprit in mediating long-term 5-HT deficits associated with fenfluramines and related SERT substrates. We propose an alternative explanation that suggests deleterious effects of SERT substrates are directly related to their current-inducing properties. Although substrate-induced currents are evoked by external substrate, they are inhibited by accumulated internal substrate (Adams and Defelice, 2003). If we assume that the uncoupled ion conductance through the transporter contributes to a deleterious effect of amphetamines to nerve cells, inhibition of it by internal substrate might be protective. Thus, the cytotoxicity of a particular SERT substrate might be inversely correlated with its affinity for the internal substrate binding site. This intriguing hypothesis is now being investigated in our laboratory. From a public health perspective, it is important that future studies clarify the mechanisms responsible for toxic effects of transporter substrates because drugs of this type are used clinically. In addition, this issue has special relevance at the present time because there is an alarming increase in the recreational misuse of synthetic designer drugs that target SERT (Baumann et al, 2012, 2013; Rosenauer et al, 2013).

\section{FUNDING AND DISCLOSURE}

HHS has received honoraria for lectures and consulting from Astra Zeneca, Lundbeck, Nycomed, Ratiopharm, Roche, Sanofi-Aventis, Serumwerk Bernburg, and TorrexCiesi Pharma. The remaining authors declare no conflict of interest.

\section{ACKNOWLEDGEMENTS}

This research was supported by the Intramural Research Program of the NIDA, NIH, DA000523-05 to MHB and the Austrian Research Fund/FWF grants F3506 and W1232 to HHS. We are indebted to Klaus Schicker for valuable comments on the manuscript.

\section{Author contributions}

MHB and HHS designed and supervised the project, analyzed data, and wrote the first draft of the manuscript. MHB, TSB and MAA designed and performed microdialysis experiments, whereas SFA analyzed post-mortem tissue concentrations of monoamines and their metabolites. JSP and RBR designed and performed the release assays in rat brain synaptosomes. SB, MHB, KS, WS and HHS designed, performed, and/or analyzed electrophysiological experiments in Xenopus laevis oocytes. All authors contributed significantly to the writing of the final version of the article.

\section{REFERENCES}

Adams SV, Defelice LJ (2003). Ionic currents in the human serotonin transporter reveal inconsistencies in the alternating access hypothesis. Biophys J 85: 1548-1559.

Appel NM, Mitchell WM, Contrera JF, De Souza EB (1990). Effects of high-dose fenfluramine treatment on monoamine uptake sites in rat brain: assessment using quantitative autoradiography. Synapse 6: 33-44.

Auerbach SB, Kamalakannan N, Rutter JJ (1990). TFMPP and RU24969 enhance serotonin release from rat hippocampus. Eur J Pharmacol 190: 51-57.

Baumann MH, Ayestas MA, Dersch CM, Rothman RB (2001). 1-(M-chlorophenyl)piperazine (mCPP) dissociates in vivo serotonin release from long-term serotonin depletion in rat brain. Neuropsychopharmacology 24: 492-501.

Baumann MH, Ayestas MA, Partilla JS, Sink JR, Shulgin AT, Daley PF et al (2012). The designer methcathinone analogs, mephedrone and methylone, are substrates for monoamine transporters in brain tissue. Neuropsychopharmacology 37: 1192-1203.

Baumann MH, Clark RD, Budzynski AG, Partilla JS, Blough BE, Rothman RB (2005). N-substituted piperazines abused by humans mimic the molecular mechanism of 3,4-methylenedioxymethamphetamine (MDMA, or 'Ecstasy'). Neuropsychopharmacology 30: 550-560.

Baumann MH, Partilla JS, Lehner KR, Thorndike EB, Hoffman AF, Holy $M$ et al (2013). Powerful cocaine-like actions of 3, 4-Methylenedioxypyrovalerone (MDPV), a principal constituent of psychoactive 'bath salts' products. Neuropsychopharmacology 38: $552-562$. 
Baumann MH, Rutter JJ, Auerbach SB (1993). Intravenous administration of the serotonin agonist $\mathrm{m}$-chlorophenylpiperazine (mCPP) increases extracellular serotonin in the diencephalon of awake rats. Neuropharmacology 32: 1381-1386.

Berger UV, Gu XF, Azmitia EC (1992). The substituted amphetamines 3,4-methylenedioxymethamphetamine, methamphetamine, p-chloroamphetamine and fenfluramine induce 5hydroxytryptamine release via a common mechanism blocked by fluoxetine and cocaine. Eur J Pharmacol 215: 153-160.

Bulling S, Schicker K, Zhang Y-W, Steinkellner T, Stockner T, Gruber CW et al (2012). The mechanistic basis for noncompetitive ibogaine inhibition of serotonin and dopamine transporters. J Biol Chem 287: 18524-18534.

Caccia S, Anelli M, Ferrarese A, Fracasso C, Garattini S (1993). The role of d-norfenfluramine in the indole-depleting effect of d-fenfluramine in the rat. Eur J Pharmacol 233: 71-77.

Cadet JL, Brannock C (1998). Free radicals and the pathobiology of brain dopamine systems. Neurochem Int 32: 117-131.

Carvelli L, Mcdonald PW, Blakely RD, Defelice LJ (2004). Dopamine transporters depolarize neurons by a channel mechanism. Proc Natl Acad Sci USA 101: 16046-16051.

Clineschmidt BV, Zacchei AG, Totaro JA, Pflueger AB, McGuffin JC, Wishousky TI (1978). Fenfluramine and brain serotonin. Ann N Y Acad Sci 305: 222-241.

Colado MI, O’Shea E, Granados R, Murray TK, Green AR (1997). In vivo evidence for free radical involvement in the degeneration of rat brain 5-HT following administration of MDMA ('ecstasy') and p-chloroamphetamine but not the degeneration following fenfluramine. Br J Pharmacol 121: 889-900.

Commins DL, Vosmer G, Virus RM, Woolverton WL, Schuster CR, Seiden LS (1987). Biochemical and histological evidence that methylenedioxymethylamphetamine (MDMA) is toxic to neurons in the rat brain. J Pharmacol Exp Ther 241: 338-345.

Connolly HM, Crary JL, McGoon MD, Hensrud DD, Edwards BS, Edwards WD et al (1997). Valvular heart disease associated with fenfluramine-phentermine. $N$ Engl J Med 337: 581-588.

Cryan JF, Harkin A, Naughton M, Kelly JP, Leonard BE (2000). Characterization of D-fenfluramine-induced hypothermia: evidence for multiple sites of action. Eur J Pharmacol 390: 275-285.

Eriksson E, Engberg G, Bing O, Nissbrandt H (1999). Effects of $\mathrm{mCPP}$ on the extracellular concentrations of serotonin and dopamine in rat brain. Neuropsychopharmacology 20: 287-296.

Fuxe K, Farnebo LO, Hamberger B, Ogren SO (1975). On the in vivo and in vitro actions of fenfluramine and its derivatives on central monoamine neurons, especially 5-hydroxytryptamine neurons, and their relation to the anorectic activity of fenfluramine. Postgrad Med J 51(Suppl 1): 35-45.

Garattini S, Buczko W, Jori A, Samanin R (1975). The mechanism of action of fenfluramine. Postgrad Med J 51 (Suppl 1): 27-35.

Gobbi M, Funicello M, Gerstbrein K, Holy M, Moya PR, Sotomayor $\mathrm{R}$ et al (2008). N,N-dimethyl-thioamphetamine and methylthioamphetamine, two non-neurotoxic substrates of 5-HT transporters, have scant in vitro efficacy for the induction of transporter-mediated 5-HT release and currents. J Neurochem 105: $1770-1780$.

Gobbi M, Mancini L, Presti ML, Mennini T (1996). Downregulation of rat brain 5-HT uptake carriers after treatment with high doses of D-fenfluramine. Brain Res 730: 165-172.

Halladay AK, Kirschner E, Hesse K, Fisher H, Wagner GC (2001). Role of monoamine oxidase inhibition and monoamine depletion in fenfluramine-induced neurotoxicity and serotonin release. Pharmacol Toxicol 89: 237-248.

Hilber B, Scholze P, Dorostkar MM, Sandtner W, Holy M, Boehm S et al (2005). Serotonin-transporter mediated efflux: a pharmacological analysis of amphetamines and non-amphetamines. Neuropharmacology 49: 811-819.
Ingram SL, Prasad BM, Amara SG (2002). Dopamine transportermediated conductances increase excitability of midbrain dopamine neurons. Nat Neurosci 5: 971-978.

Invernizzi R, Kmieciak-Kolada K, Samanin R (1982). Is receptor activation involved in the mechanism by which $(+)$-fenfluramine and $(+)$-norfenfluramine deplete 5-hydroxytryptamine in the rat brain? Br J Pharmacol 75: 525-530.

Johnson MP, Conarty PF, Nichols DE (1991). [3H]monoamine releasing and uptake inhibition properties of 3,4-methylenedioxymethamphetamine and p-chloroamphetamine analogues. Eur J Pharmacol 200: 9-16.

Johnson MP, Huang XM, Oberlender R, Nash JF, Nichols DE (1990). Behavioral, biochemical and neurotoxicological actions of the alpha-ethyl homologue of p-chloroamphetamine. Eur $J$ Pharmacol 191: 1-10.

Johnson MP, Nichols DE (1990). Comparative serotonin neurotoxicity of the stereoisomers of fenfluramine and norfenfluramine. Pharmacol Biochem Behav 36: 105-109.

Jones DC, Duvauchelle C, Ikegami A, Olsen CM, Lau SS, de la Torre $\mathrm{R}$ et al (2005). Serotonergic neurotoxic metabolites of ecstasy identified in rat brain. J Pharmacol Exp Ther 313: 422-431.

Kleven MS, Seiden LS (1989). D-, L- and DL-fenfluramine cause long-lasting depletions of serotonin in rat brain. Brain Res 505 351-353.

Lyles J, Cadet JL (2003). Methylenedioxymethamphetamine (MDMA, Ecstasy) neurotoxicity: cellular and molecular mechanisms. Brain Res Brain Res Rev 42: 155-168.

Mager S, Min C, Henry DJ, Chavkin C, Hoffman BJ, Davidson N et al (1994). Conducting states of a mammalian serotonin transporter. Neuron 12: 845-859.

Malberg JE, Seiden LS (1997). Administration of fenfluramine at different ambient temperatures produces different core temperature and 5-HT neurotoxicity profiles. Brain Res 765: 101-107.

McCann UD, Seiden LS, Rubin LJ, Ricaurte GA (1997). Brain serotonin neurotoxicity and primary pulmonary hypertension from fenfluramine and dexfenfluramine. A systematic review of the evidence. JAMA 278: 666-672.

Meinild A-K, Sitte HH, Gether U (2004). Zinc potentiates an uncoupled anion conductance associated with the dopamine transporter. J Biol Chem 279: 49671-49679.

Murray TK, Williams JL, Misra A, Colado MI, Green AR (1996). The spin trap reagent PBN attenuates degeneration of 5-HT neurones in rat brain induced by p-chloroamphetamine but not fenfluramine. Neuropharmacology 35: 1615-1620.

Nichols DE, Brewster WK, Johnson MP, Oberlender R, Riggs RM (1990). Nonneurotoxic tetralin and indan analogues of 3,4(methylenedioxy)amphetamine (MDA). J Med Chem 33: 703-710.

O'Callaghan JP, Miller DB (1994). Neurotoxicity profiles of substituted amphetamines in the C57BL/6J mouse. J Pharmacol Exp Ther 270: 741-751.

Pettibone DJ, Williams M (1984). Serotonin-releasing effects of substituted piperazines in vitro. Biochem Pharmacol 33: 1531-1535.

Rosenauer R, Luf A, Holy M, Freissmuth M, Schmid R, Sitte HH (2013). A combined approach using transporter-flux assays and mass spectrometry to examine psychostimulant street drugs of unknown content. ACS Chem Neurosci 4: 182-190.

Rothman RB, Ayestas MA, Dersch CM, Baumann MH (1999). Aminorex, fenfluramine, and chlorphentermine are serotonin transporter substrates. Implications for primary pulmonary hypertension. Circulation 100: 869-875.

Rothman RB, Baumann MH (2002). Therapeutic and adverse actions of serotonin transporter substrates. Pharmacol Ther 95: 73-88.

Rothman RB, Baumann MH (2009). Serotonergic drugs and valvular heart disease. Expert Opin Drug Saf 8: 317-329.

Rothman RB, Baumann MH, Dersch CM, Romero DV, Rice KC, Carroll FI et al (2001). Amphetamine-type central nervous 
system stimulants release norepinephrine more potently than they release dopamine and serotonin. Synapse 39: 32-41.

Rothman RB, Baumann MH, Savage JE, Rauser L, McBride A, Hufeisen SJ et al (2000). Evidence for possible involvement of $5-\mathrm{HT}(2 \mathrm{~B})$ receptors in the cardiac valvulopathy associated with fenfluramine and other serotonergic medications. Circulation 102: 2836-2841.

Rothman RB, Blough BE, Woolverton WL, Anderson KG, Negus SS, Mello NK et al (2005). Development of a rationally designed, low abuse potential, biogenic amine releaser that suppresses cocaine self-administration. J Pharmacol Exp Ther 313: 1361-1369.

Rothman RB, Clark RD, Partilla JS, Baumann MH (2003). (+)Fenfluramine and its major metabolite, $(+)$-norfenfluramine, are potent substrates for norepinephrine transporters. J Pharmacol Exp Ther 305: 1191-1199.

Rudnick G (2002). Mechanisms of biogenic amine neurotransmitter transporters. Contemp Neurosci Neurotransmitter Transp Struct Funct Regul 28-52.

Sabol KE, Richards JB, Seiden LS (1992). Fluoxetine attenuates the DL-fenfluramine-induced increase in extracellular serotonin as measured by in vivo dialysis. Brain Res 585: 421-424.

Sanders-Bush E, Bushing JA, Sulser F (1975). Long-term effects of p-chloroamphetamine and related drugs on central serotonergic mechanisms. J Pharmacol Exp Ther 192: 33-41.

Schicker K, Uzelac Z, Gesmonde J, Bulling S, Stockner T, Freissmuth $\mathrm{M}$ et al (2012). Unifying concept of serotonin transporter-associated currents. J Biol Chem 287: 438-445.

Schmidt CJ, Abbate GM, Black CK, Taylor VL (1990). Selective 5-hydroxytryptamine2 receptor antagonists protect against the neurotoxicity of methylenedioxymethamphetamine in rats. J Pharmacol Exp Ther 255: 478-483.

Schoeffter P, Hoyer D (1989). Interaction of arylpiperazines with 5-HT1A, 5-HT1B, 5-HT1C and 5-HT1D receptors: do discriminatory 5-HT1B receptor ligands exist? Naunyn Schmiedebergs Arch Pharmacol 339: 675-683.

Schuldiner S, Steiner-Mordoch S, Yelin R, Wall SC, Rudnick G (1993). Amphetamine derivatives interact with both plasma membrane and secretory vesicle biogenic amine transporters. Mol Pharmacol 44: 1227-1231.

Schwartz D, Hernandez L, Hoebel BG (1989). Fenfluramine administered systemically or locally increases extracellular serotonin in the lateral hypothalamus as measured by microdialysis. Brain Res 482: 261-270.

Seiden LS, Sabol KE (1996). Methamphetamine and methylenedioxymethamphetamine neurotoxicity: possible mechanisms of cell destruction. NIDA Res Monogr 163: 251-276.
Series HG, Cowen PJ, Sharp T (1994). p-Chloroamphetamine (PCA), 3,4-methylenedioxy-methamphetamine (MDMA) and d-fenfluramine pretreatment attenuates d-fenfluramine-evoked release of 5-HT in vivo. Psychopharmacology (Berl) 116: 508-514.

Shi WX, Pun CL, Zhang XX, Jones MD, Bunney BS (2000). Dual effects of D-amphetamine on dopamine neurons mediated by dopamine and nondopamine receptors. J Neurosci 20: 3504-3511.

Sitte HH, Scholze P, Schloss P, Pifl C, Singer EA (2000). Characterization of carrier-mediated efflux in human embryonic kidney 293 cells stably expressing the rat serotonin transporter: a superfusion study. J Neurochem 74: 1317-1324.

Sprague JE, Everman SL, Nichols DE (1998). An integrated hypothesis for the serotonergic axonal loss induced by 3,4methylenedioxymethamphetamine. Neurotoxicology 19: 427-441.

Staack RF, Paul LD, Springer D, Kraemer T, Maurer HH (2004). Cytochrome $\mathrm{P} 450$ dependent metabolism of the new designer drug 1-(3-trifluoromethylphenyl)piperazine (TFMPP). In vivo studies in Wistar and Dark Agouti rats as well as in vitro studies in human liver microsomes. Biochem Pharmacol 67: 235-244.

Steinkellner T, Freissmuth M, Sitte HH, Montgomery T (2011). The ugly side of amphetamines: short- and long-term toxicity of 3,4methylenedioxymethamphetamine (MDMA, 'Ecstasy'), methamphetamine and D-amphetamine. Biol Chem 392: 103-115.

Steranka LR, Sanders-Bush E (1979). Long-term effects of fenfluramine on central serotonergic mechanisms. Neuropharmacology 18: 895-903.

Sulzer D (2011). How addictive drugs disrupt presynaptic dopamine neurotransmission. Neuron 69: 628-649.

Wrona MZ, Dryhurst G (2001). A putative metabolite of serotonin, tryptamine-4,5-dione, is an irreversible inhibitor of tryptophan hydroxylase: possible relevance to the serotonergic neurotoxicity of methamphetamine. Chem Res Toxicol 14: 1184-1192.

Xie T, Tong L, McLane MW, Hatzidimitriou G, Yuan J, McCann U et al (2006). Loss of serotonin transporter protein after MDMA and other ring-substituted amphetamines. Neuropsychopharmacology 31: 2639-2651.

Zaczek R, Battaglia G, Culp S, Appel NM, Contrera JF, De Souza EB (1990). Effects of repeated fenfluramine administration on indices of monoamine function in rat brain: pharmacokinetic, dose response, regional specificity and time course data. J Pharmacol Exp Ther 253: 104-112.

(c) (1) (2) This work is licensed under a Creative Commons (c) Attribution-NonCommercial-ShareAlike 3.0 Unported License. To view a copy of this license, visit http:// creativecommons.org/licenses/by-nc-sa/3.0/ 